\title{
Sphingosine kinase inhibitors: A patent review
}

\author{
MENGDA CAO $^{1,2}$, CHUNMEI JI ${ }^{2}$, YANJUN ZHOU ${ }^{2}$, WEN HUANG ${ }^{2}$, \\ WEIWEI NI ${ }^{2}$, XUNLIANG TONG ${ }^{1}$ and JI-FU WEI ${ }^{2}$ \\ ${ }^{1}$ Department of Geriatrics, Beijing Hospital, National Center of Gerontology, Dongcheng, Beijing 100730; \\ ${ }^{2}$ Research Division of Clinical Pharmacology, The First Affiliated Hospital of \\ Nanjing Medical University, Nanjing, Jiangsu 210029, P.R. China
}

Received October 21, 2016; Accepted January 30, 2018

DOI: $10.3892 / \mathrm{ijmm} .2018 .3505$

\begin{abstract}
Sphingosine kinases (SphKs) catalyze the conversion of the sphingosine to the promitogenic/migratory product, sphingosine-1-phosphate (S1P). SphK/S1P pathway has been linked to the progression of cancer and various other diseases including allergic inflammatory disease, cardiovascular diseases, rejection after transplantation, the central nervous system, and virus infections. Therefore, SphKs represent potential new targets for developing novel therapeutics for these diseases. The history and development of SphK inhibitors are discussed, summarizing SphK inhibitors by their structures, and describing some applications of SphK inhibitors. We concluded: i) initial SphK inhibitors based on sphingosine have low specificity with several important off-targets. Identification the off-targets that would work synergistically with SphKs, and developing compounds that target the unique C4 domain of SphKs should be the focus of future studies. ii) The modifications of SphK inhibitors, which are devoted to increasing the selectivity to one of the two isoforms, now focus on the alkyl length, the spacer between the head and linker rings, and the insertion and the position of lipidic group in tail region. iii) SphK/S1P signaling pathway holds therapeutic values for many diseases. To find the exact function of each isoform of SphKs increasing the number of SphK inhibitor clinical trials is necessary.
\end{abstract}

Correspondence to: Dr Xunliang Tong, Department of Geriatrics, Beijing Hospital, National Center of Gerontology, 1 Dahua Road, Dongcheng, Beijing 100730, P.R. China

E-mail: tongxunliang@163.com

Professor Ji-Fu Wei, Research Division of Clinical Pharmacology, The First Affiliated Hospital, Nanjing Medical University, 300 Guangzhou Road, Nanjing, Jiangsu 210029, P.R. China

E-mail:weijifu@hotmail.com

Key words: sphingosine kinases, sphingosine-1-phosphate, inhibitor, selective, structure, disease

\section{Contents}

1. Introduction

2. The history and development of SphK inhibitor

3. SphK inhibitors

4. The applications of SphK inhibitors

5. Discussion

\section{Introduction}

Sphingosine kinases (SphKs) are biological lipid kinases that regulate the sphingolipid metabolic pathway. SphKs control multiple important cell processes and play an important role in numerous hyperproliferative and inflammatory diseases.

Briefly, the de novo way of sphingolipid synthesis is a conduction from serine and palmitate to the formation of 3-ketodihydrosphingosine through serine palmitoyltransferase (SPT) enzyme. In turn, 3-keto-dihydrosphingosine is reduced to dihydrosphingosine, followed the acylation by a (dihydro)-ceramide synthase (also known as lass or CerS) (1). After desaturation of dihydroceramide, ceramide is produced. Ceramide is a central hub of sphingolipid metabolism which can be phosphorylated by ceramide kinase to form ceramide-1-phosphate; glycosylated by glucosylceramide synthase or galactosylceramide synthase; converted to sphingomyelin by sphingomyelin synthase; or finally broken down by a ceramidase to form sphingosine (2). Sphingosine can be recycled into sphingolipid pathways by ceramide synthase or it can be phosphorylated by one of two SphKs (SphK1 and SphK2) to form sphingosine-1-phosphate (S1P). Also, the product S1P can be dephosphorylated to regenerate sphingosine by S1P phosphatases. The only exit pathway of sphingolipid pathways is metabolism of S1P mediated by S1P lyase (3) (Fig. 1). These interconnected metabolites interact with specific protein targets, such as kinases, phosphatases and G protein coupled receptors (S1P receptors) (4), to exert their cell responses.

SphKs are the only enzymes that catalyze ATP-dependent phosphorylation of sphingosine to S1P. The balance between the cellular levels of S1P and ceramide/sphingosine, so-called sphingolipid rheostat, acts as an important regulator of cell 


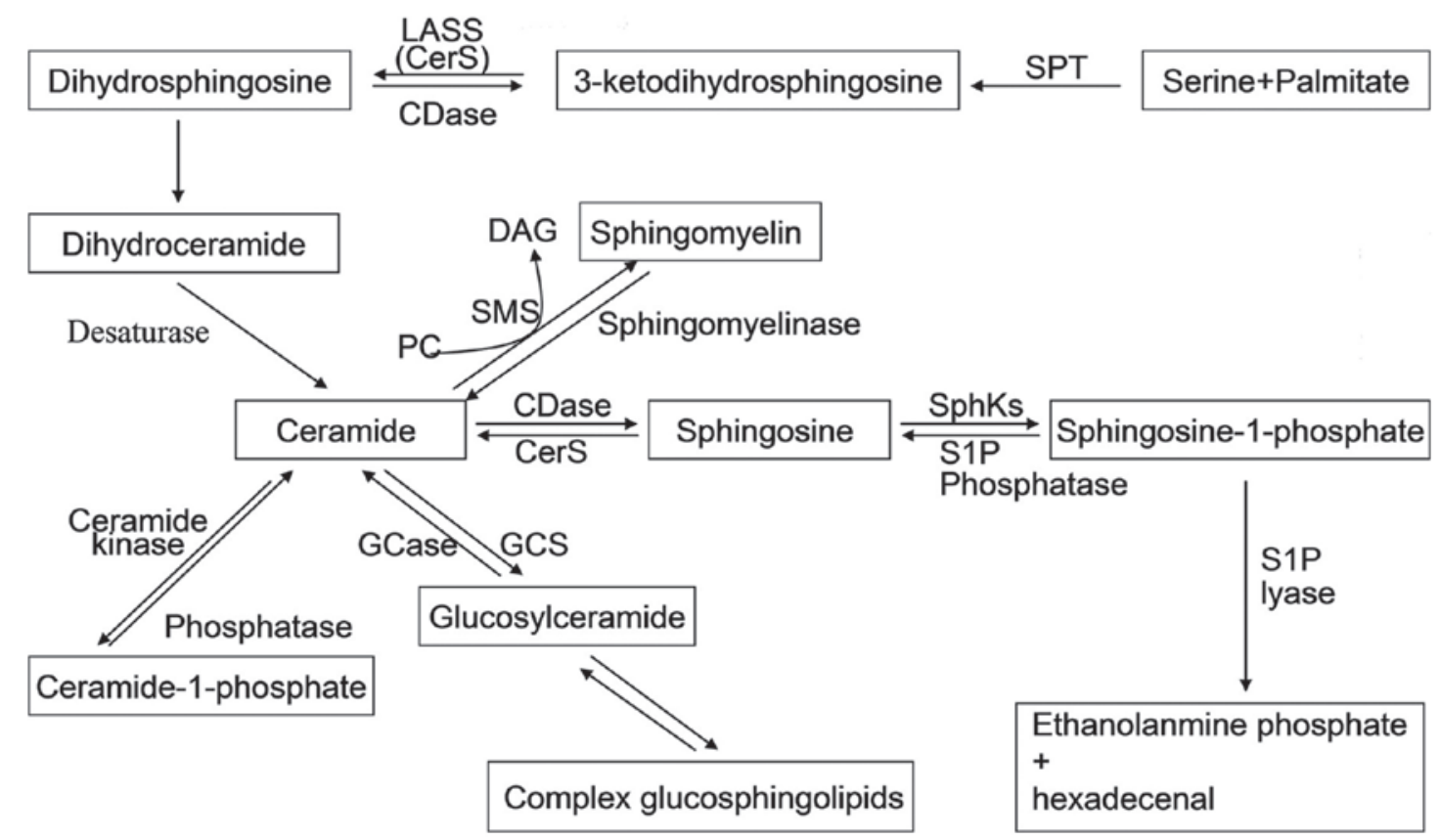

Figure 1. Sphingolipid metabolic pathway. Ceramide is in the center of sphingolipid metabolism, generated by de novo-sphingolipid synthesis or by sphingomyelin degradation. The de novo synthesis of ceramide begins with 3-ketodihydrosphingosine formed by serine and palmitate through the action of SPT; has experienced the process of the formation of dihydrosphingosine, dihydroceramide, and is eventually generated by the action of desaturases. Ceramide can be glycosylated by glucosylceramide synthase or galactosylceramide synthase; converted to sphingomyelin by sphingomyelin synthase; or finally broken down by a ceramidase to form sphingosine. Sphingosine can be phosphorylated by one of two SphKs (SphK1 and SphK2) to form sphingosine-1-phosphate (S1P). The only exit pathway of sphingolipid pathways is metabolism of S1P mediated by S1P lyase. Most of sphingolipids can be recycled into sphingolipid pathways by specific enzymes. SPT, serine palmitoyl transferase; CDase, ceramidase; DAG, diacylglycerol; GCase, glucosyl ceramidase; GCS, glucosylceramide synthase; PC, phosphatidylcholine; SphKs, sphingosine kinases; SMS, sphingomyelin synthase.

fate (5). S1P is both an extracellular messenger and an intracellular second messenger. As an extracellular messenger, S1P is a specific and high-affinity ligand for a family of G-proteincoupled receptors (GPCRs) (6,7). S1P binding to these receptors could trigger a wide range of cellular responses, including proliferation, inhibition of apoptosis, formation of actin stress fibres, stimulation of adherent junctions and enhanced extracellular matrix assembly (8-11). As an intracellular second messenger, S1P stimulates various plasma-membrane receptors, such as platelet-derived growth factor receptor (PDGFR) and Fc $\gamma$ receptor 1 ( Fc $\gamma \mathrm{RI})(12,13)$. Inhibition of $\mathrm{SphKs}$ strongly reduces cellular events triggered by these receptors. Now, SphK/S1P signaling is considered to be involved in many physiological and pathological processes, including cardiovascular system, inflammation, cancer process, transplantation, virus infections and central nervous system, which will be introduced in detail in the application section of this review (14-19).

SphKs have five conserved domains (C1-C5). C1-C3 domains are also found in ceramide kinase (CERK) and diacylglycerol kinases (DAGK), whereas C4 domain appears to be unique domain in SphKs (20). The two SphK isoforms (SphK1 and SphK2) regulate the phosphorylation metabolism. Compared to SphK1, SphK2 has 240 additional amino acids. Human SphK1 localizes to chromosome 17 (17q25.2), whereas SphK2 maps to chromosome 19 (19q13.2) (21), indicating different functions of SphKs. SphK1 exists mostly in cytoplasm and migrates to plasma membrane upon phosphorylation. It is involved in the formation of cancers by enhancing cancer cell proliferation and invasion $(22,23)$. Moreover, SphK1 expression is correlated with severity and poor prognosis of cancers, and chemotherapy resistance (24-27). Also, SphK1 participates in immunological and inflammatory responses in human body (28). SphK2 localizes in the nucleus to inhibit DNA synthesis and regulate HDAC1/2 activity (29). Downregulation of SphK2 inhibits the effects of inflammation, proliferation and migration in tumor cells (30-33). Specifically, SphK2 affects the function of mitochondria involved in the central nervous system diseases (34). Levels of mRNA encoding $S p h K 1 / 2$ are significantly higher in tumors of rectum, stomach, kidney, colon, uterus, ovary, breast and lung compared with normal tissues from the same patient (35). Administration of polynucleotides encoding SphKs can induce blood vessel formation $(36,37)$. Overall, the evidence suggests that inhibition of SphKs may be an effective therapy for many diseases (38).

Due to the function of SphKs and S1P, the SphK/S1P pathway is now considered as a novel and innovative target for the treatment of many diseases. Since the past decade, there is growing interest in developing novel inhibitors of SphKs and their application in clinical practice. This review consists of three parts. The first part summarizes the history and development of SphK inhibitors; the second part introduces SphK inhibitors by their structures; the third part describes some applications of SphK inhibitors.

\section{The history and development of SphK inhibitor}

Sphingolipids, are a class of lipids containing a backbone of sphingoid bases, a set of aliphatic amino alcohols that includes sphingosine. They were discovered in brain extracts in the 1870s and named after the mythological Sphinx because 
of their enigmatic nature $(39,40)$. Sphingosine was discovered around 1880 by Thudichum, who isolated it from the hydrolysis products of phrenosin, characterized it as a base of empirical composition $\mathrm{C}_{17} \mathrm{H}_{35} \mathrm{NO}_{2}$, and described a number of its salts (41). In 1968, Stoffel et al proposed the importance of SphK is not restricted to catabolism of sphingolipids (42). In 1989, Hannun and Bell found that sphingosine and lysosphingolipids elicited a variety of cellular responses, including antagonism of phorbol eater-induced responses, blockage of platelet and neutrophil function, and inhibition of growth factor action (43). Later in the same year, Okazaki et al demonstrated the existence of a 'sphingomyelin cycle' in human cells and suggested the products of sphingolipids may play a role in cell differentiation (44). In 1998, Olivera et al purified SphKs from rat kidney for the first time (20), providing the basis for molecular characterization of key enzymes in sphingolipid signaling. To date, two mammalian SphKs have been characterized, cloned and sequenced.

Initial SphK inhibitor development has utilized molecules derived from sphingosine, including L-threo-dihydrosphingosine (DHS:Sfingol), N,N-dimethylsphingosine (DMS) and N,N,N-trimethylsphingosine (TMS). They block the activities of both SphK1 and SphK2 by competing with the natural substrate sphingosine. Safingol has been proven to show therapeutic value in treating patients with locally advanced or metastatic solid tumors, which has now entered phase I clinical trials (NCT00084812). However, these sphingosine mimic compounds have low specificity with several important off-targets, such as protein kinase C (PKC), ceramide synthase (CerS) (45). In 2003, French et al revealed four different types of nolipidic small molecules, SKI-I SKI-II; SKI-III; SKI-IV, with SphK inhibitory effect at submicromolar to micromolar concentrations (38). These four derivatives were shown to be selective toward human SphKs compared with a panel of human lipid and protein kinases (38). Moreover, these compounds had antitumor activity in vivo without obvious toxicity, providing the first evidence that SphK inhibitor can be developed as anticancer drugs. In 21st century, selective SphK inhibitor drugs attracted more attention. ABC294640 is the first selective SphK2 inhibitor, which has completed phase I clinical trials recently for treatment of advanced solid tumors (NCT01488513). The first SphK1-specific inhibitor, SK1-I, was described by Paugh et al in 2008 (46). From then, more selective SphK compounds were developed.

\section{SphK inhibitors}

\section{Sphingosine-based SphK inhibitors}

Sphingoguanidine based SphK inhibitors. Sphingoguanidine based SphK inhibitors are composed of a sphingolipid backbone and a guanidine moiety at the head. The guanidine region mimics the polar head of sphingosine. Guanidine is believed to be able to interact with ATP directly in the catalytic center of some enzymes and to impede the phosphorylation reaction $(47,48)$. Representative compounds of this type of SphK inhibitor are SLR080811, SLP120701 and LCL351 (Fig. 2).

Among the compounds in this category, LCL351 is the most effective agent. It exhibits half maximal inhibitory concentration $\left(\mathrm{IC}_{50}\right)$ values of 40 and $300 \mathrm{nmol} / 1$ for inhibition of SphK1 and SphK2 respectively, indicating a special selectivity for
SphK1 $(47,48)$. Except the long chain followed by guanidine moiety, these sphingoguanidine based SphK inhibitors usually bear an oxadizole linker ring. The structure-activity relationship studies indicated that the removal of a hydroxyl group on the pyrrolidine ring of sphingoguanidine based inhibitors acted as a molecular switch to selective SphK2 inhibition (49). Furthermore, insertion of a single methylene unit as a spacer between the oxadiazole and pyrrolidine rings can increase the selectivity to inhibit the function of SphK1 in this category (49).

Amidine based SphK inhibitors. Amidine-based SphK inhibitors are also structural analogues of sphingosine that prevent from the substrate binding to the domain of the SphKs, including VPC96091, VPC96077, and compound 11 in patent WO2013/119946A1 (50-52) (Fig. 2). However, the hydroxyl group located in the polar head of sphingosine is removed in this category. Considering that the hydroxyl group is responsible for phosphorylation (53), these compounds, which are difficult to phosphorylate, would be more effective in suppressing the activity of SphKs.

The amidine-based SphK inhibitors showed high selective activity to SphK1 with in vitro potency in the nanomolar range. Compound 11 is the representative one with 705-fold selectivity for SphK1 and is the most selective SphK1 inhibitor reported until now (50). The unique torsional angle of the cyclopropane ring in compound 11 provides improved presentation of amidine in the active site. Biological evaluation of amidine based SphK inhibitors reveals substantial differences in inhibitory quality of molecules containing isomeric oxadiazoles. Compounds containing 3-aryl display significantly higher potency and selectivity for SphK1 than those containing 5-aryl 1,2,4-oxadiazole isomers (compound 20 in patent WO2013/119946A1) (Fig. 2), while the compounds containing 1,3,4-oxadiazoles (compound 30 in patent WO2013/119946A1) (Fig. 2) display intermediate potency (52). Moreover, meta-substitution in the phenyl ring increases the efficacy for all isomers (50).

Bicyclic aryl based SphK inhibitors. Bicyclic aryl based SphK inhibitors are fused bicyclic sphingosine analogs. The fused bicycle is naphthalene, isoquinoline, quinoline, quinazoline or indole $(54,55)$. Among them, Naphthalene based compounds are studied most thoroughly. Naphthalene based SphK inhibitors are tail region modifications of sphingosine, including SLC5091592, SLC5081308 and SLC5111312 (Fig. 2). Removal of the lipophilic tail completely abolishes the inhibitory activity of naphthalene based SphK inhibitors. Also it is necessary for the tail region to bear internal phenyl ring(s) (56). Detailed investigations on the tail region of a scaffold that features a lipophilic naphthalene ring holding SphK inhibition activity were conducted by Congdon et al (57). These analogues possess a binding mode similar to sphingosine in the ligand binding pocket and are competitive with sphingosine, independent of ATP.

SLC5091592 is the most representative and potent agent of naphthalene-based SphK inhibitors, which incorporates a 4-trifluomethylbenzyl 'tail' and displays high selectivity toward SphK2 (57). The replacement of 4-trifluomethylbenzyl results in significant inhibition of SphK2 at $1 \mu \mathrm{M}(\mu \mathrm{mol} / \mathrm{l})$ inhibitor concentration without any inhibition of $\mathrm{SphK} 1$, as the $\mathrm{CF}_{3}$ group can impact SphK2 selectivity. The corresponding meta version was also generated by Congdon et al, but it was less potent (57). Other halogens $(\mathrm{Br}$ and $\mathrm{Cl})$ are equally potent in the meta and 
<smiles>[R]CC1([R])N(CC)C([N+]([R])=O)N([R])C1([R])[R]</smiles>

Sphingoguanidine based formula<smiles>CCCCCc1ccc(-c2noc(C3CCCN3C(=N)N)n2)cc1</smiles>

LCL351

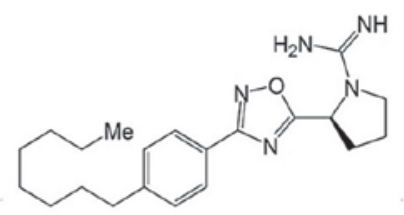

SLR080811<smiles>CCCCCCCCc1ccc(-c2noc(C3CCN3C(=N)N)n2)cc1</smiles>

SLP120701<smiles>[R16]CC([R])([R])C(N)N[Y]</smiles>

Amidine based formula<smiles>CCCCCCCCCCc1cccc(-c2noc([C@H](C(=N)N)C3CC3)n2)c1</smiles>

Compound 11<smiles>CCCCCCCCCc1ccc(C(=O)N2CCCC2C(=N)N)cc1</smiles>

VPC96091<smiles>CCCCCCCCCc1ccc(C(=O)N2CCCC2C(=N)N)cc1</smiles>

VPC96077<smiles>CCCCCCCCCCCCc1ccc(-c2nnc(C3(C(=N)N)CC3)o2)cc1</smiles>

Compound 20

Compound 30<smiles>[R20]c1ccc2cc(-c3noc(C4C([R])CCN4C(=N)N)n3)ccc2c1</smiles>

Naphthalene based formula

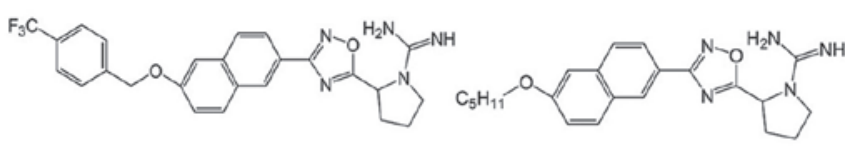

SLC5081308<smiles>CCOC1CCC2CC(c3noc(C4C(O)CCN4C(N)N)n3)CCC2C1</smiles>

SLC511312<smiles>CCCCc1ccc(CCC(N)(CO)CO)cc1</smiles>

FTY720<smiles>COCC(N)(C=COP(O)O)CCc1ccc(C=O)cc1</smiles>

FTY720-OCH3<smiles>NC(C=COP(O)O)(CO)CCc1ccc(CCO)cc1</smiles>

(S)-FTY720-vinylphosphonate,<smiles>[CH]c1ccc(C[C@H](O)[C@@H](N)CO)cc1</smiles>

SG-12

Figure 2. The structure of some sphingosine-based sphingosine kinase (SphK) inhibitors. Sphingoguanidine based derivatives include SLR080811, SLP120701 and LCL351; amidine-based derivatives include a VPC96091, VPC96077, compound 11, compound 20 and compound 30; bicyclic aryl based derivatives include SLC5091592, SLC5081308 and SLC5111312; amino-alcohol based derivatives include FTY720, (S)-FTY720-vinylphosphonate, FTY720-OCH 3 and SG-12.

para positions. Also, the length of the molecule is of great significance. The ideal head to tail (positive charge to terminal methyl group) length is $\sim 18-21$ atoms (57). Moreover, there is a dependence on SphK2 activity and selectivity with alkyl chain length of naphthalene based inhibitors, suggesting a larger lipid binding pocket in SphK2 compared to SphK1 $(56,58)$.

Amino-alcohol based SphK inhibitors. Amino-alcohol based SphK inhibitors are sphingosine analog inhibitors bearing an amino alcohol head group, including FTY720, (S)-FTY720-vinylphosphonate, FTY720-OCH3 and SG-12 (Fig. 2). The amino alcohol group is molecular target of SphK2 competing with sphingosine (53). Apart from the amino alcohol group, the structures of these derivatives all contain a 1,4-disubstituted phenyl ring acting as a rigid linker group and a lipophilic tail which is important for interactions with hydrophobic binding pocket of S1P receptors (S1PRs) (53).

FTY720 (2-amino-2-[2-(4-octylphenyl) ethyl] propane-1, 3-diol), also known as fingolimod, is one of most studied sphin- gosine analog inhibitors. It is phosphorylated by SphK2, and the product (FTY720-P) acts as an agonist of four of the five S1PRs (excluding S1PR2), with concentration for $50 \%$ of maximal effect $\left(E_{50}\right)$ values in the nanomolar range (59). This compound was approved by US Food and Drug Administration (FDA) in September 21, 2010 for the treatment of multiple sclerosis and has been used in the clinic to quell symptoms and slow the progression of multiple sclerosis. Moreover, it completed phase 3 clinical trials for its efficacy and safety in de novo adult renal transplant recipients (NCT00239876).

\section{Small molecule SphK inhibitors}

Lipidic small molecule SphK inhibitors. Benzene sulfonamide-based inhibitors of SphKs were identified through a structure-base approach to target ATP-binding pocket of SphKs. These compounds are docked into ATP-binding pocket of SphKs, and are predicted to form close associations with Asn22, Arg24, Thr54, Ser79, Gly80, Asp81, Gly82, Leu83 and 
<smiles>[R]c1c([R])c([R])c(NS(=O)(=O)c2c([R])c([R])c([R])c([R])c2[R])c([R])c1[R]</smiles>

Benzene sulfonamide-based formula

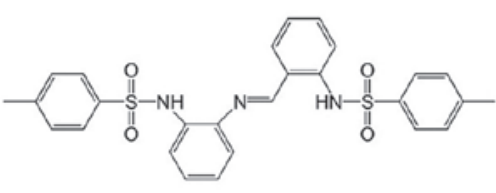

MP-A08

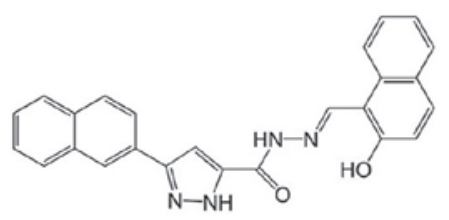

SKI-I

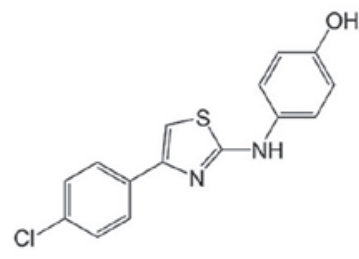

SKI-II

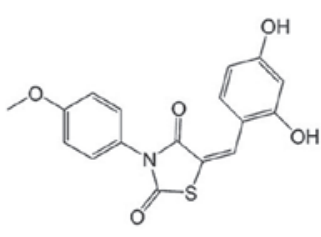

SKI-III

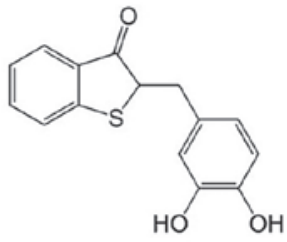

SKI-IV

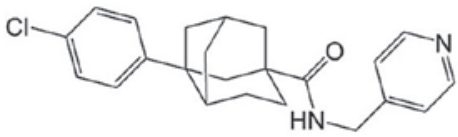

ABC294640

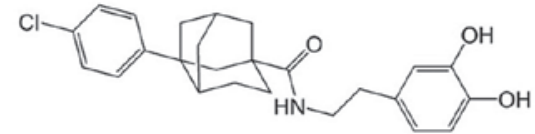

ABC294735

Figure 3. The structure of some small molecule sphingosine kinase (SphK) inhibitors. Lipidic small molecule SphK inhibitors include benzene sulfonamide-based derivatives, such as MP-A08; nolipidic small molecules SphK inhibitors include SKI-I, SKI-II, SKI-III, SKI-IV, ABC294640 and ABC294735.

Ser112 of ATP-binding pocket in SphKs (60). To confirm the orientation binding of these compounds, its ability of inhibiting the ATP-binding pocket mutants of SphKs was assessed in patent WO2016007993 (A1) through alanine mutagenesis. Their inhibition was reduced by $\sim 3$-fold by the T54A, L83A, R185A and S112A mutations and 2 -fold by the S79A, R24A and R191A mutations. These findings confirmed the inhibitor target of ATP-binding pocket of SphKs (60).

The most representative compounds in this category is MP-A08 (Fig. 3), 4-methyl-N-[2-[[2-[(4-ethylphenyl)sulfonylamino]phenyl]iminomethyl]phenyl] benzenesulfonamide, containing two benzenesulfonamide groups joined by a benzylidene-aniline group. To assess the selectivity, MP-A08 was tested against purified recombinant SphKs. MP-A08 showed no inhibition of human DAGK and only weak influence on CERK. This hinted that inhibitors of this type may overcome at least some of the off-target effects of sphingosine-like molecules. MP-A08 is a higher affinity inhibitor of SphK2 than SphK1, with inhibitory constant (Ki) values of $6.9 \pm 0.8$ and $27 \pm 3 \mathrm{mM}$, respectively (60).

Nolipidic small molecule SphK inhibitors. SKI-I, SKI-II, SKI-III and SKI-IV were identified by a high throughput screen by Smith and co-workers in 2003 (Fig. 3). They are the first nolipidic small molecules of SphK inhibitors. Among them, SKI-II, 2-(p-hydroxyanilino)-4-(p-chlorophenyl)thiazole, is the most extensively studied compound, with high oral bioavailability and limited toxicity (61). It is an SphK1/2-dual inhibitor which favors SphK2 inhibition (62) and has been commercialized (63). SKI-II induces lysosomal degradation of SphK1 rather than directly inhibiting catalytic SphK1 activity or competing the ATP-binding site (64). However, whether this is an SphK1-specific effect or a more general effect also affecting other proteins determined for lysosomal degradation remains unclear, thus providing additional targets for SKI-II (64). A recent study revealed a dual mechanism of action for SKI-II: abrogating estrogen receptor (ER) signaling, possibly through direct binding to ER, similar to tamoxifen (63), which is consistent with previous speculation of its additional targets.

A series of phenyladamantane-based compounds showed the inhibitory activity to SphKs. They are competitive inhibitors in respect to sphingosine. The most famous compound is ABC294640 (Fig. 3). ABC294640, 3-(4-chlorophenyl)adamantane-1-carboxylic acid (pyridin-4-ylmethyl) amide, is the first SphK2 inhibitor with a Ki of $9.8 \mu \mathrm{M}$, and it reduces the amount of S1P in intact cells (65). It shows great therapeutic value in cancer treatment (32) and has completed phase I clinical trials for advanced solid tumors recently (NCT01488513). Moreover, ABC294640 was found not only to inhibit STAT3 phosphorylation, which is the key signaling pathways in regulating cholangiocarcinoma cell proliferation and survival, but also to induce autophagy of cholangiocarcinoma cells (66). Furthermore, it possesses the same antiestrogenic activity as SKI-II, similar to tamoxifen (67). Apart from ABC294640, $\mathrm{ABC} 294735$ is another potent compound in this series (Fig. 3). It is a modification of the pyridylmethyl substituent on amide group of ABC294640 by a dihydroxyphenyl ring. Different from ABC294640, it induced inhibition in a dose-dependent manner of both SphK1 and SphK2 $\left(\mathrm{IC}_{50}=10 \mu \mathrm{M}\right)(126)$. Therefore, it is considered a dual inhibitor of SphK1 and SphK2.

SphK inhibitors from natural sources. Nature has provided us with basis of many medicines in clinical use today. Many compounds 
from natural sources have also been recognized as SphK inhibitors. For example, SphK inhibitors B-5354a, b and c are from marine bacterium, SANK 71896. They inhibit SphKs activity with $\mathrm{IC}_{50}$ values of 21,58 and $38 \mu \mathrm{M}$, respectively (68). The structures of these compounds were elucidated by a combination of spectroscopic analyses to be new esters of 4-amino-3-hydroxybenzoic acid with long-chain unsaturated alcohols (69). Three functional groups including the long unsaturated aliphatic chain, 4-amino and 3-hydroxyl were identified (69). Other inhibitors were developed from natural sources, include Jaspine B (70), F-12509A, and polyphenols. Although these inhibitors are moderately potent, with in vitro $\mathrm{Ki}$ ranging from 2 to $58 \mathrm{mM}$, their selectivity and large-scale production capabilities remain unknown.

\section{The applications of SphK inhibitors}

Cancer. SphK1/2 are expressed 2-8-fold higher in various cancer tissues (e.g., breast, lung, ovarian, stomach and colon cancers) than in normal control tissues in both messenger (m)RNA and protein levels (35), indicating participation of SphKs in evolution and progression in cancer. They take part in cancer progression through two major different ways: one is SphKs themselves as oncogenes, the the other is their functions of metabolites.

Firstly, SphKs may act as oncogenes, involved in oncogenic H-Ras-mediated transformation. Xia et al proved that SphK1 acted as an oncogene, involving in a novel signaling pathway for Ras activation (23). Furthermore, SphK1 itself could induce cancer cell migration and tumor angiogenesis through its key role in epidermal growth factor (EGF) directed motility (71,72). SphK1 and SphK2 can promote breast cancer cell growth through mediating mitogenic action of insulin (73). However, there is an opposite example that specific inhibition of SphK1 had no effect on the proliferation and survival of head and neck carcinoma cells (74), which means that different cancer show different tissue specificity of SphKs.

Secondly, the products of SphKs, especially S1P, can participate in cancer progression. S1P can specifically bind to amino-terminal ring domain of tumor necrosis factor (TNF) receptor-associated factor 2 (TRAF2) (75,76), an E3 ubiquitin ligase that modulates TNF- $\alpha$-induced activation of nuclear factor- $\kappa \mathrm{B}(\mathrm{NF}-\kappa \mathrm{B})$ signaling. It also activates signal transducer activator of transcription 3 (STAT3) (77-81). So, S1P can serve as a master switch in carcinogenesis by activation of two transcriptional regulators, TRAF2 and STAT3. S1P not only exerts function by binding to other receptors, but also precedes its function by its own receptors.

Many SphK inhibitors mentioned above have antitumor activity, some of which have entered the stage of clinical trials. For example, MP-A08 reduces the growth of human lung adenocarcinoma in a mouse xenograft model by both inducing tumor cell apoptosis and inhibiting tumor angiogenesis; ABC294640 was reported in reducing the growth of prostate and colorectal cancer $(32,82)$, and also effective in other solid tumors, which was completed in phase I clinical trials (NCT01488513); and SKI-II can induce growth inhibition and apoptosis in human gastric cancer $(83,84)$.

Allergic and inflammatory diseases. Allergic inflammatory disease is caused by hypersensitivity of the immune system and leads to inflammation. It was reported that level of S1P was increased in bronchoalveolar lavage fluid of allergic asthma after allergen challenge, revealing a potential mechanism of S1P involving in allergic inflammatory diseases (85). The mechanisms are varied and introduced below.Firstly,S1P mediates intercellular adhesion molecule-1 (ICAM-1) through p38 mitogen-activated protein kinase (MAPK) and p42/p44 MAPK-dependent Akt activation, and then causes lung injury (86). Secondly, intracellular S1P can induce cyclooxygenase-2 (COX-2) expression via activation of S1PR2 and p42/p44 MAPK-dependent signaling in renal mesangial cells, leading to enhanced prostaglandin $\mathrm{E}_{2}$ $\left(\mathrm{PGE}_{2}\right)$ formation and cell migration $(15,87)$. Apart from COX-2, CD23 expression is significantly increased in S1P-treated animal models. CD23 is a low-affinity receptor for IgE and considered to regulate $\operatorname{IgE}$ production $(88,89)$. High expression of CD23 causes high level of $\operatorname{IgE}$, which is responsible for the activation of mast cells (90). Thirdly, IgE mediated mast cell activation leads to the activation of SphK, resulting in increased formation of S1P (90), which forms a vicious circle. Administration of S1P to nude mice does not elicit airway smooth muscle hyper-reactivity and lung inflammation, which indicates a Th2-like bias mechanism of S1P (85). Fourthly, S1P signaling plays a role in immune-cell trafficking $(91,92)$. S1P regulates both the homing of immune cells to lymphoid organs and their egress into blood and lymph (93). For example, S1PR1 is decisive for T and B cell egress from lymph nodes and for the exit of mature thymocytes, both conventional T cells and natural killer T (NKT) cells (94).

The therapeutic value of SphK inhibitors in allergic inflammatory diseases has been confirmed in animal models (16). SK1-I and DMS were both reported to reduce ovalbumin-induced airway hyper-responsiveness (AHR) and airway inflammation in mice sensitized to ovalbumin significantly (95). These compounds decrease the number of eosinophils and levels of the cytokines, TNF- $\alpha$, chemokines eotaxin and chemokine ligand 2 (CCL2) in bronchoalveolar lavage fluid. SphK inhibitors also inhibit activation of $\mathrm{NF}-\kappa \mathrm{B}$ in lungs (96), a master transcription factor that regulates the expression of proinflammatory cytokines. Recently, a clinical trial recruited for evaluation the S1P as a novel biomarker in food allergy (NCT01776489). Thus, SphKs are novel therapeutic targets for the treatment of allergic diseases.

Cardiovascular diseases. Cardiovascular disease (CVD) is a general term for conditions affecting the heart or blood vessels. The majority of S1P in plasma is associated with high-density lipoproteins (HDL), and the amount of HDL-S1P affects the quantity and quality of HDL-dependent functions $(97,98)$. A number of studies have linked plasma HDL-S1P to the incidence of coronary artery disease (CAD) i) HDL-S1P was lower in patients with stable CAD than in healthy individuals; ii) in contrast, HDL-S1P was higher in CAD independent of HDL-cholesterol than in healthy individuals and even higher in acute myocardial infarction (AMI); iii) HDL-S1P correlated negatively with the severity of coronary atherosclerosis $(99,100)$. So the plasma S1P may act as a biomarker for discriminating patients with myocardial infarction (MI) and stable CAD from healthy individuals. Also, S1P takes an important part in chronic cardiac remodeling. Firstly, SphK1/S1P/S1PR1 signaling is a main cause of collagen deposition and myofibroblast activation stimulated by transforming growth factor (TGF), which contributes to cardiac fibrosis and remodeling (101). Secondly, the NF- $\mathrm{BB}$ and STAT3 
in the cardiomyocyte can be activated by cardiac SphK1/S1P/ S1PR1 signaling, leading to the overproduction of proinflammatory cytokines and pathological cardiac remodeling $(102,103)$. Thirdly, SphK1/S1P/S1PR1 signaling regulates $\beta 1$-adrenergic receptor $(\beta 1-\mathrm{AR})$ stimulation-induced activation of proinflammatory responses in the cardiomyocyte, a well-recognized mechanism of chronic cardiac inflammation following MI (104). Stimulation of $\beta 1$-AR upregulates SphK1 expression and increases S1P production in the cardiomyocyte (104). So cardiac SphK1/S1P/S1PR1 signaling plays a crucial role in the regulation of cardiomyocyte pro-inflammatory responses and contributes to cardiac remodeling. Furthermore, as we mentioned before, SphK1 and S1P are critical for EGF-based angiogenesis. S1P signaling regulates vascular function (105), such as vascular tone and endothelial barrier, the regulation of blood pressure, and anti-atherosclerotic effect. S1PR1 also regulates cardiac function by modulating intracellular $\mathrm{Ca}^{2+}$ homeostasis and $\mathrm{Na}^{+} / \mathrm{H}^{+}$ exchange through its inhibitory effect on adenylate cyclase (106). These key findings on SphK and S1P may offer novel therapeutic approaches to CVD.

However, there is no approved clinical use or clinical trials of SphK inhibitors in treatment of CVD. Only a few compounds have been confirmed to show therapeutic values in CVD on mice or rats, for example, SKI-II exacerbating atherosclerosis in low-density lipoprotein receptor-deficient mice on high cholesterol diet. SphK/S1P-based therapy is a completely new area in CVD treatment.

Transplantation. Graft-versus-host disease (GVHD) and transplant vasculopathy (TV) represent the main cause of graft failure and reduce the ratio of long-term success after organ transplantation $(107,108)$. As mentioned above, SPHK1/S1P signaling is involved in immune response and vascular function which are both important factors of transplantation. S1PR1 is essential for lymphocyte recirculation (109). It regulates lymphocyte egress from both thymus and peripheral lymphoid organs, which can reduce the chance of lymphocyte reaching the lesion site and prolong the survival time of the transplanted organ $(109,110)$. Also, many studies have linked SphK1/S1P signaling to the prognostic of transplantation: i) transplant arteriosclerosis was markedly reduced in animals with SphK1 suppressed by fish oil (111); ii) GVHD and graft rejection was prevented by antagonizing the function of S1P in rat small bowel transplantation (107); iii) SphK1/S1P pathway contributed to in vivo intimal hyperplasia and caused the transplant vasculopathy (108).

FTY720, an SphK inhibitor, reduces the number of lymphocytes in the peripheral circulation selectively and prolongs the survival of transplanted organs, with no harm to the immune response to virus and immune memory function $(110,112)$. It has been used on patients who receive transplantation in clinic and has showed great synergistic effect with cyclosporin A, FK506 and other first-line immunosuppressants (113-116). FTY720 finished its phase 3 clinical trails for its efficacy and safety in de novo adult renal transplant recipients in 2011 and has achieved a clear effect and slight adverse reaction in preventing immune rejection after transplantation.

The central nervous system. SphK/S1P has different roles in different central nervous diseases (117). SphK2 plays primary roles by regulation of mitochondria function and modulation to dopaminergic neurons in Parkinson's disease $(118,119)$. Mitochondrial dysfunction is a feature of Parkinson's disease. SphK2 is located predominantly in mitochondria. The inhibition of SphK2 decreases the expression of peroxisome proliferatoractivated receptor $\gamma$ coactivator- $1 \alpha$ (PGC-1 $1 \alpha)$ and its downstream targets nuclear respiratory factor 1 (NRF-1) and mitochondrial transcription factor A (TFAM), which are the key transcription factors regulating mitochondrial function (118). Also, SphK2/ S1P regulates the survival of the dopaminergic neurons (119). Dopaminergic neurons are related to the clinical development of Parkinson's disease. In Alzheimer's disease (AD), amyloid- $\beta$ $(A \beta)$ induces neuronal apoptosis, which is an important part in the pathogenesis of AD. siRNA knockdown of SphK1 expression increases the load of $A \beta$, altering the toxicity of $A \beta$, and worsening learning and memory ability in animal models $(120,121)$. S1P formed by SphK2 can bind to full-length b-secretase-1 (BACE1) and increase its proteolytic activity $(122,123)$. SphK2 is also involved in nociception. SphK2 knockout mice demonstrated its facilitation of nociceptive transmission during the late response (124), but the exact mechanism is still unknown.

In multiple sclerosis, the immunomodulating drug FTY720, also a sphingosine-based inhibitor of SphKs and S1PR, completed phase 3 clinical trials for relapsing-remitting multiple sclerosis and was approved for oral treatment of multiple sclerosis by FDA, September 22, 2010. It can cross the blood-brain barrier (BBB) and accumulate in the central nervous system. FTY720 acts on brain cells directly and provides protection against the neurodegenerative component (125). In addition, because SphK1 and SphK2 exert different effect on the central nervous system, development of selective SphK inhibitors becomes particularly important.

Virus infections. Negative-strand RNA virus, including influenza virus and measles virus, have become major health concerns and significant economic burden throughout the world. SphK1overexpressing cells are more susceptible to viral infection and have more progeny virus and viral protein expression than control cells after being infected, which provides supporting evidence of increased viral replication in SphK-cells. SphK2 is co-localized with viral RNA and nonstructural proteins. Targeted impairment of SphK2 expression or function significantly inhibits virus infection. Furthermore, affinity purification-mass spectrometry studies revealed that SphK2 associates with a number of proteins involved in cellular gene expression specifically during viral infection, suggesting its role in viral replication (19).

DMS and SKI-II have been identified to inhibit influenza viral protein expression in MDCK cells. These two inhibitors also suppress the production of infectious influenza virus particles from the cells. SKI-II displays a stronger activity on inhibiting virus production with an $\mathrm{EC}_{50}$ of $2.5 \mu \mathrm{M}$, than DMS, which has an $\mathrm{EC}_{50}$ of $4.1 \mu \mathrm{M}$ (19). At present, there is no SphK inhibitor entering clinical trials for virus infections and animal experiments are also limited, so this application needs many further studies.

\section{Discussion}

SphKs are key enzymes in the sphingolipid metabolic pathway which phosphorylates sphingosine into S1P, thus providing an 
essential checkpoint that regulates the relative levels of ceramide, sphingosine and S1P. The two isoforms of SphKs (SphK1 and SphK2) are the only enzymes responsible for the equilibrium between the S1P and sphingosine (62). They differ in the enzyme kinetic properties, temporal and spatial distribution, implyiing that they have distinct physiological functions. S1P participates in many cellular functions, including cell proliferation, cell morphology, tumor cell invasion, platelet aggregation, endothelial cell chemotaxis and angiogenesis. SphK/S1P signaling pathway has become a focal point in biological research, with therapeutic values for many diseases, including cancer, central nervous system diseases, virus infections, rejection after transplantation, cardiovascular diseases, and inflammatory diseases.

With the intense interest in SphK/S1P signaling pathway, many SphK inhibitors were developed. Three of five conserved domains identified within SphK are found in DAGK and CERK, whereas C4 appears to be unique in SphKs. Also SphK inhibitors have been shown to inhibit the ERK and Akt signaling pathways as a downstream event of SphK inhibition. These signaling pathways and kinases are also involved in many other physiological and pathological processes. So SphK inhibitors more or less have some off-targets effects. Identification of these off-targets that would work synergistically with SphKs, and develop compounds to target the unique $\mathrm{C} 4$ domain should be the focus of future studies.

Most SphK inhibitors target the substrate of SphKs or binding pocket of sphingosine or ATP in SphKs. Sphingosine-based SphK inhibitors are the structural modifications of sphingosine in its polar head, lipophilic tail or the linker. Initial sphingosine-based SphK inhibitors, including DHS, DMS and TMS, have low specificity, with several important off-targets effects. Later on, more selective inhibitors were identified, including amidine based SphK inhibitors, naphthalene based SphK inhibitors, sphingoguanidine based SphK inhibitors and many small molecules. The modifications, increasing the selectivity to one of the two isoforms, now focus on the alkyl length, the spacer between the head and linker rings, and the insertion and the position of lipidic group in tail region.

Recently, SphK1 is the most developed SphK inhibitor. Some promising potent and selective SphK1 inhibitors are appearing with best biochemically characterized inhibitor in vitro and in vivo. Unfortunately, current SphK 2 inhibitors are moderately potent and only $\sim 10$-fold selective. The first SphK2 selective inhibitor described, ABC294640, has been tested in a variety of animal models of disease with some success, but some of the effects observed in in vivo studies may be attributed to off-target effects of this low-potency compound. SLR080811 is a secondgeneration SphK2 inhibitor that is $\sim 10$-fold more potent than ABC294640 but no more selective. A curious aspect of SphK2 is its absence in the results in mice in circulating S1P levels that are three times that of normal (SphK1 ablation results in one-half normal levels). SLR080811 treatment recapitulates this phenomenon. If the propensity to raise S1P levels is a general property of SphK2 inhibitors and if this effect extends beyond rodent species, then application of selective SphK inhibitors could be used to raise or lower circulating S1P levels.

The physiological role of S1P is complex, and SphKs play a pivotal role in the S1P signaling axis. Numerous in vitro and in vivo studies indicate targeting $\mathrm{SphKs}$ for the potential treatment of many diseases. SphK1 and SphK2 were reported to hold therapeutic values, however, whether the inhibition of one of them alone is enough remains uncertain. More kinases are targeted, more side effects will occur, so it is necessary to find the exact function of each isoforms of SphKs. With further investigation of S1P/SphK signal pathway, the mechanisms of its role in different systems will be better understood. Candidate SphK inhibitors will be optional therapeutic choice and need to be proven by clinical trials. Only a few compounds have entered the clinical trials. The assumption that animal or in vitro responses would be predictive of human in vivo reaction is not considered to be accurate. So we consider that increasing the number of SphK inhibitors in clinical trials is necessary.

\section{Acknowledgements}

Not applicable.

\section{Funding}

This project was sponsored by the grants from the National Natural Science Foundation of China (nos. 81400037, 81571568, 31340073 and 81273274); Beijing Hospital Nova Project (no. BJ-2016-038). The Priority Academic Program Development of Jiangsu Higher Education Institutions (PAPD); the Six Talents Peak projects of Jiangsu Province (to JFW).

\section{Availability of data and material}

The datasets used and/or analyzed during the current study are available from the corresponding author on reasonable request.

\section{Authors' contributions}

$\mathrm{XT}$ and JFW conceived and designed this review. MC, CJ, YZ, $\mathrm{WH}$ and WN collected materials regarding sphingosine kinase inhibitors. MC wrote the paper. XT and JFW reviewed and edited the manuscript. All authors read and approved the manuscript.

\section{Ethics approval and consent to participate}

Not applicable.

\section{Consent for publication}

Not applicable.

\section{Competing interests}

The authors declare that they have no competing interests.

\section{References}

1. Orr Gandy KA and Obeid LM: Targeting the sphingosine kinase/ sphingosine 1-phosphate pathway in disease: Review of sphingosine kinase inhibitors. Biochim Biophys Acta 1831: 157-166, 2013.

2. Kitatani K, Idkowiak-Baldys J and Hannun YA: The sphingolipid salvage pathway in ceramide metabolism and signaling. Cell Signal 20: 1010-1018, 2008 .

3. Hannun YA and Obeid LM: Principles of bioactive lipid signalling: Lessons from sphingolipids. Nat Rev Mol Cell Biol 9: 139-150, 2008 
4. Herr DR, Grillet N, Schwander M, Rivera R, Müller U and Chun J: Sphingosine 1-phosphate (S1P) signaling is required for maintenance of hair cells mainly via activation of S1P2. J Neurosci 27: 1474-1478, 2007.

5. Pitman MR, Powell JA, Coolen C, Moretti PA, Zebol JR, Pham DH, Finnie JW, Don AS, Ebert LM, Bonder CS, et al: A selective ATP-competitive sphingosine kinase inhibitor demonstrates anti-cancer properties. Oncotarget 6: 7065-7083, 2015.

6. Archbold JK, Martin JL and Sweet MJ: Towards selective lysophospholipid GPCR modulators. Trends Pharmacol Sci 35 219-226, 2014

7. Ishii I, Fukushima N, Ye X and Chun J: Lysophospholipid receptors: Signaling and biology. Annu Rev Biochem 73: 321-354, 2004

8. Zhang Q, Peyruchaud O, French KJ, Magnusson MK and Mosher DF: Sphingosine 1-phosphate stimulates fibronectin matrix assembly through a Rho-dependent signal pathway. Blood 93: 2984-2990, 1999

9. Melendez AJ: Sphingosine kinase signalling in immune cells: Potential as novel therapeutic targets. Biochim Biophys Acta 1784: 66-75, 2008

10. Porcelli AM, Ghelli A, Hrelia S and Rugolo M: Phospholipase D stimulation is required for sphingosine-1-phosphate activation of actin stress fibre assembly in human airway epithelial cells. Cell Signal 14: 75-81, 2002.

11. Meng Y, Xu Z, Wu F, Chen W, Xie S, Liu J, Huang X and Zhou Y: Sphingosine-1-phosphate suppresses cyclophosphamide induced follicle apoptosis in human fetal ovarian xenografts in nude mice. Fertil Steril 102: 871-877.e873, 2014

12. Wang H, Cai KY, Li W and Huang H: Sphingosine-1-phosphate induces the migration and angiogenesis of Epcs through the Akt signaling pathway via Sphingosine-1-phosphate receptor 3/platelet-derived growth factor receptor- $\beta$. Cell Mol Biol Lett 20: 597-611, 2015.

13. Florey O and Haskard DO: Sphingosine 1-phosphate enhances Fc gamma receptor-mediated neutrophil activation and recruitment under flow conditions. J Immunol 183: 2330-2336, 2009.

14. Stieber F and Wienke D: Inhibitors of sphingosine kinase. Patent SG181643 A1. 2010.

15. Hla T, Sanchez T, Paik J and Claffey KP: Methods of inhibiting vascular permeability and apoptosis. Patent WO/2005/002559 A2 . Filed June 18, 2004; issued January 13, 2005

16. Lynch K and Santos W: Sphingosine kinase inhibitors. Patent WO2016054261 A1. Filed 30 September, 2015; issued 7 April, 2016.

17. Smith $\mathrm{C}$ and French $\mathrm{K}$ : Methods for the treatment and prevention of inflammatory diseases. Patent US20060270630 A1. Filed 19 May 2006; issued 30 November, 2006.

18. Hahm B, Seo YJ and Alexander S: Modulation of sphingosine 1-phosphate metabolizing enzymes for the treatment of negative-strand rna virus infections. Patent WO2012166859 A2. Filed 31 May, 2012; issued 6 December, 2012.

19. Sinha UK and Masood R: Compositions and methods of sphingosine kinase inhibitors for use thereof in cancer therapy. Patent WO2008067560 A9. Filed November 30, 2007; issued July 17 2008

20. Olivera A, Kohama T, Tu Z, Milstien S and Spiegel S: Purification and characterization of rat kidney sphingosine kinase. J Biol Chem 273: 12576-12583, 1998

21. Lai WQ, Wong WS and Leung BP: Sphingosine kinase and sphingosine 1-phosphate in asthma. Biosci Rep 31: 145-150, 2011.

22. Li J, Song Z, Wang Y, Yin Y, Liu Y, Yuan R and Nan X: Overexpression of SphK1 enhances cell proliferation and invasion in triple-negative breast cancer via the PI3K/AKT signaling pathway. Tumour Biol 37: 10587-10593, 2016.

23. Xia P, Gamble JR, Wang L, Pitson SM, Moretti PA, Wattenberg BW, D'Andrea RJ and Vadas MA: An oncogenic role of sphingosine kinase. Curr Biol 10: 1527-1530, 2000.

24. Meng XD, Zhou ZS, Qiu JH, Shen WH, Wu Q and Xiao J: Increased SPHK1 expression is associated with poor prognosis in bladder cancer. Tumour Biol 35: 2075-2080, 2014.

25. Matula K, Collie-Duguid E, Murray G, Parikh K, Grabsch H, Tan P, Lalwani S, Garau R, Ong Y, Bain G, et al: Regulation of cellular sphingosine-1-phosphate by sphingosine kinase 1 and sphingosine-1-phopshate lyase determines chemotherapy resistance in gastroesophageal cancer. BMC Cancer 15: 762, 2015.

26. Selvam SP and Ogretmen B: Sphingosine kinase/sphingosine 1-phosphate signaling in cancer therapeutics and drug resistance. Handb Exp Pharmacol 216: 3-27, 2013.
27. Zhang Y, Wang Y, Wan Z, Liu S, Cao Y and Zeng Z: Sphingosine kinase 1 and cancer: A systematic review and meta-analysis. PLoS One 9: e90362, 2014.

28. Iwabuchi K, Nakayama H, Oizumi A, Suga Y, Ogawa H and Takamori K: Role of ceramide from glycosphingolipids and its metabolites in immunological and inflammatory responses in humans. Mediators Inflamm 2015: 120748, 2015.

29. Alemany R, van Koppen CJ, Danneberg K, Ter Braak M and Meyer Zu Heringdorf D: Regulation and functional roles of sphingosine kinases. Naunyn Schmiedebergs Arch Pharmacol 374: 413-428, 2007.

30. Wang Q, Li J, Li G, Li Y, Xu C, Li M, Xu G and Fu S: Prognostic significance of sphingosine kinase 2 expression in non-small cell lung cancer. Tumour Biol 35: 363-368, 2014.

31. Zhang L, Liu X, Zuo Z, Hao C and Ma Y: Sphingosine kinase 2 promotes colorectal cancer cell proliferation and invasion by enhancing MYC expression. Tumour Biol 37: 8455-8460, 2016.

32. Xun C, Chen MB, Qi L, Tie-Ning Z, Peng X, Ning L, Zhi-Xiao C and Li-Wei W: Targeting sphingosine kinase 2 (SphK2) by ABC294640 inhibits colorectal cancer cell growth in vitro and in vivo. J Exp Clin Cancer Res 34: 94, 2015

33. Liu Q, Rehman H, Shi Y, Krishnasamy Y, Lemasters JJ, Smith CD and Zhong Z: Inhibition of sphingosine kinase-2 suppresses inflammation and attenuates graft injury after liver transplantation in rats. PLoS One 7: e41834, 2012.

34. Strub GM, Paillard M, Liang J, Gomez L, Allegood JC, Hait NC, Maceyka M, Price MM, Chen Q, Simpson DC, et al: Sphingosine-1-phosphate produced by sphingosine kinase 2 in mitochondria interacts with prohibitin 2 to regulate complex IV assembly and respiration. FASEB J 25: 600-612, 2011

35. Shida D, Takabe K, Kapitonov D, Milstien S and Spiegel S: Targeting SphK1 as a new strategy against cancer. Curr Drug Targets 9: 662-673, 2008

36. Liau G, Stefansson S and Su J: Induction of blood vessel formation through administration of polynucleotides encoding sphingosine kinases. Patent WO2002028406 A2. Filed October 5, 2001; issued October 5, 2002.

37. Pitson SM, Wattenberg BW, Xia P, Dandrea RJ, Gamble JR and Vadas MA: Sphingosine kinase enzyme.Patent WO2000070028 A1. Filed May 12, 2000; issued November 23, 2000.

38. French KJ, Schrecengost RS, Lee BD, Zhuang Y, Smith SN, Eberly JL, Yun JK and Smith CD: Discovery and evaluation of inhibitors of human sphingosine kinase. Cancer Res 63: 5962-5969, 2003.

39. Chun J and Hartung HP: Mechanism of action of oral fingolimod (FTY720) in multiple sclerosis. Clin Neuropharmacol 33: 91-101, 2010.

40. Spiegel S and Milstien S: Sphingosine-1-phosphate: An enigmatic signalling lipid. Nat Rev Mol Cell Biol 4: 397-407, 2003.

41. Lai WQ, Melendez AJ and Leung BP: Role of sphingosine kinase and sphingosine-1-phosphate in inflammatory arthritis. World J Biol Chem 1: 321-326, 2010.

42. Stoffel W, Sticht G and LeKim D: Synthesis and degradation of spingosine bases in Hansenula ciferrii. Hoppe Seylers Z Physiol Chem 349: 1149-1156, 1968.

43. Hannun YA and Bell RM: Functions of sphingolipids and sphingolipid breakdown products in cellular regulation. Science 243: 500-507, 1989

44. Okazaki T, Bell RM and Hannun YA: Sphingomyelin turnover induced by vitamin D3 in HL-60 cells. Role in cell differentiation. J Biol Chem 264: 19076-19080, 1989.

45. Pitman MR and Pitson SM: Inhibitors of the sphingosine kinase pathway as potential therapeutics. Curr Cancer Drug Targets 10: 354-367, 2010.

46. Paugh SW, Paugh BS, Rahmani M, Kapitonov D, Almenara JA, Kordula T, Milstien S, Adams JK, Zipkin RE, Grant S, et al: A selective sphingosine kinase 1 inhibitor integrates multiple molecular therapeutic targets in human leukemia. Blood 112: 1382-1391, 2008

47. Szulc Zdzislaw M: Bielawska Alicja, Obeid Lina M, Hannun Yusuf A, Norris James. Xiang Liu. Sphingo-guanidines and their use as inhibitors of sphingosine kinase. Patent WO2010078247 A1. Filed 28 December, 2009; issued 8 July, 2010.

48. Szulc ZM, Bielawska A, Obeid LM, Hannun YA, Norris J and Xiang L: Sphingo-guanidines and their use as ihibitors of sphingosine kinase. Patent US2012035268 A1. Filed 28 December, 2009; issued 9 February, 2012

49. Patwardhan NN, Morris EA, Kharel Y, Raje MR, Gao M, Tomsig JL, Lynch KR and Santos WL: Structure-activity relationshipstudiesandin vivo activity of guanidine-basedsphingosine kinase inhibitors: Discovery of SphK1- and SphK2-selective inhibitors. J Med Chem 58: 1879-1899, 2015. 
50. Houck JD, Dawson TK, Kennedy AJ, Kharel Y, Naimon ND, Field SD, Lynch KR and Macdonald TL: Structural requirements and docking analysis of amidine-based sphingosine kinase 1 inhibitors containing oxadiazoles. ACS Med Chem Lett 7: 487-492, 2016

51. Lynch KR, MacDonald TL and Mathews TP: Imidamide sphingosine kinase inhibitors. Patent WO2011/020116 A1. Filed 16 August, 2010; issued 17 February, 2011.

52. University Of Virginia Patent Foundation, Santos WL, Lynch KR, Macdonald TL, Kennedy A, Kharel Y, Raje MR and Houck J: Long chain base sphingosine kinase inhibitors. Patent WO2013/119946A1. Filed 8 February, 2013; issued 15 August, 2013.

53. Plano D, Amin S and Sharma AK: Importance of sphingosine kinase (SphK) as a target in developing cancer therapeutics and recent developments in the synthesis of novel SphK inhibitors. J Med Chem 57: 5509-5524, 2014

54. Thomas J, Liu XG, Kumaravel G, Guckian KM, Caldwell RD, Ma B, Lin EY, Zheng GZ and Taveras AG: Bicyclic aryl sphingosine 1-phosphate analogs. Patent NZ597596 A. 2014.

55. Thomas J, Liu XG, Kumaravel G, Guckian KM, Caldwell RD, Ma B, Lin EY, Zheng GZ and Taveras AG: Bicyclic aryl sphingosine 1-phosphate analogs. Patent US2016129023 A1. Filed 5 October, 2015; issued 12 May, 2016.

56. Congdon MD, Childress ES, Patwardhan NN, Gumkowski J, Morris EA, Kharel Y,Lynch KR and Santos WL: Structure-activity relationship studies of the lipophilic tail region of sphingosine kinase 2 inhibitors. Bioorg Med Chem Lett 25: 4956-4960, 2015.

57. Congdon MD, Kharel Y, Brown AM, Lewis SN, Bevan DR Lynch KR and Santos WL: Structure-activity relationship studies and molecular modeling of naphthalene-based sphingosine kinase 2 inhibitors. ACS Med Chem Lett 7: 229-234, 2016.

58. Knott K, Kharel Y, Raje MR, Lynch KR and Santos WL: Effect of alkyl chain length on sphingosine kinase 2 selectivity. Bioorg Med Chem Lett 22: 6817-6820, 2012.

59. Brinkmann V, Davis MD, Heise CE, Albert R, Cottens S, Hof R, Bruns C, Prieschl E, Baumruker T, Hiestand P, et al: The immune modulator FTY720 targets sphingosine 1-phosphate receptors. J Biol Chem 277: 21453-21457, 2002.

60. Pitman MR and Pitson SM: Benzene sulfonamide-based inhibitors of sphingosine kinases. Patent WO2016007993 A1. Filed 16 July, 2015; issued 21 January, 2016.

61. French KJ, Upson JJ, Keller SN, Zhuang Y, Yun JK and Smith CD: Antitumor activity of sphingosine kinase inhibitors. J Pharmacol Exp Ther 318: 596-603, 2006.

62. Gao P, Peterson YK, Smith RA and Smith CD: Characterization of isoenzyme-selective inhibitors of human sphingosine kinases. PLoS One 7: e44543, 2012.

63. Antoon JW, Meacham WD, Bratton MR, Slaughter EM, Rhodes LV, Ashe HB, Wiese TE, Burow ME and Beckman BS Pharmacological inhibition of sphingosine kinase isoforms alters estrogen receptor signaling in human breast cancer. J Mol Endocrinol 46: 205-216, 2011.

64. Ren S, Xin C, Pfeilschifter J and Huwiler A: A novel mode of action of the putative sphingosine kinase inhibitor 2-(p-hydroxyanilino)-4-(p-chlorophenyl) thiazole (SKI II): induction of lysosomal sphingosine kinase 1 degradation. Cell Physiol Biochem 26: 97-104, 2010.

65. French KJ, Zhuang Y, Maines LW, Gao P, Wang W, Beljanski V, Upson JJ, Green CL, Keller SN and Smith CD: Pharmacology and antitumor activity of ABC294640, a selective inhibitor of sphingosine kinase-2. J Pharmacol Exp Ther 333: 129-139, 2010

66. Ding X, Chaiteerakij R, Moser CD, Shaleh H, Boakye J, Chen G, Ndzengue A, Li Y, Zhou Y, Huang S, et al: Antitumor effect of the novel sphingosine kinase 2 inhibitor ABC294640 is enhanced by inhibition of autophagy and by sorafenib in human cholangiocarcinoma cells. Oncotarget 7: 20080-20092, 2016

67. Antoon JW, White MD, Meacham WD, Slaughter EM, Muir SE, Elliott S, Rhodes LV, Ashe HB, Wiese TE, Smith CD, et al: Antiestrogenic effects of the novel sphingosine kinase-2 inhibitor ABC294640. Endocrinology 151: 5124-5135, 2010.

68. Kono K, Tanaka M, Mizuno T, Kodama K, Ogita T and Kohama T: B-535a, b and c, new sphingosine kinase inhibitors, produced by a marine bacterium; taxonomy, fermentation, isolation, physicochemical properties and structure determination. J Antibiot (Tokyo) 53: 753-758, 2000

69. Kono K, Tanaka M, Ogita T and Kohama T: Characterization of B-5354c, a new sphingosine kinase inhibitor, produced by a marine bacterium. J Antibiot (Tokyo) 53: 759-764, 2000.

70. Salma Y, Lafont E, Therville N, Carpentier S, Bonnafé MJ Levade T, Génisson Y and Andrieu-Abadie N: The natural marine anhydrophytosphingosine, Jaspine B, induces apoptosis in melanoma cells by interfering with ceramide metabolism. Biochem Pharmacol 78: 477-485, 2009.
71. Sarkar S, Maceyka M, Hait NC, Paugh SW, Sankala H, Milstien S and Spiegel S: Sphingosine kinase 1 is required for migration, proliferation and survival of MCF-7 human breast cancer cells. FEBS Lett 579: 5313-5317, 2005.

72. Gamble J, Vadas M, Pitson S, Xia P and Limaye V: Method of modulating epithelial cell activity by modulating the functional levels of sphingosine kinase. Patent US20060205688A1. Filed 14 October, 2003; issued 14 September, 2006

73. Dai L, Qi Y, Chen J, Kaczorowski D, Di W, Wang W and Xia P: Sphingosine kinase (SphK) 1 and $\mathrm{SphK} 2$ play equivalent roles in mediating insulin's mitogenic action. Mol Endocrinol 28 197-207, 2014

74. Schnute ME, McReynolds MD, Kasten T, Yates M, Jerome G, Rains JW, Hall T, Chrencik J, Kraus M, Cronin CN, et al: Modulation of cellular S1P levels with a novel, potent and specific inhibitor of sphingosine kinase-1. Biochem J 444: 79-88, 2012.

75. Park ES, Choi S, Shin B, Yu J, Yu J, Hwang JM, Yun H, Chung YH, Choi JS, Choi Y, et al: Tumor necrosis factor (TNF) receptor-associated factor (TRAF)-interacting protein (TRIP) negatively regulates the TRAF2 ubiquitin-dependent pathway by suppressing the TRAF2-sphingosine 1-phosphate (S1P) interaction. J Biol Chem 290: 9660-9673, 2015.

76. Alvarez SE, Harikumar KB, Hait NC, Allegood J, Strub GM, Kim EY, Maceyka M, Jiang H, Luo C, Kordula T, et al: Sphingosine-1-phosphate is a missing cofactor for the E3 ubiquitin ligase TRAF2. Nature 465: 1084-1088, 2010

77. Garris CS, Wu L, Acharya S, Arac A, Blaho VA, Huang Y, Moon BS, Axtell RC, Ho PP, Steinberg GK, et al: Defective sphingosine 1-phosphate receptor 1 (S1P1) phosphorylation exacerbates TH17-mediated autoimmune neuroinflammation. Nat Immunol 14: 1166-1172, 2013.

78. Nguyen AV, Wu YY and Lin EY: STAT3 and sphingosine-1-phosphate in inflammation-associated colorectal cancer. World J Gastroenterol 20: 10279-10287, 2014.

79. Theiss AL: Sphingosine-1-phosphate: Driver of NFKB and STAT3 persistent activation in chronic intestinal inflammation and colitis-associated cancer. JAKSTAT 2: e24150, 2013

80. Liang J, Nagahashi M, Kim EY, Harikumar KB, Yamada A, Huang WC, Hait NC, Allegood JC, Price MM, Avni D, et al: Sphingosine-1-phosphate links persistent STAT3 activation, chronic intestinal inflammation, and development of colitis-associated cancer. Cancer Cell 23: 107-120, 2013

81. Degagné E, Pandurangan A, Bandhuvula P, Kumar A, Eltanawy A, Zhang M, Yoshinaga Y, Nefedov M, de Jong PJ, Fong LG, et al: Sphingosine-1-phosphate lyase downregulation promotes colon carcinogenesis through STAT3-activated microRNAs. J Clin Invest 124: 5368-5384, 2014

82. McNaughton M, Pitman M, Pitson SM, Pyne NJ and Pyne S Proteasomal degradation of sphingosine kinase 1 and inhibition of dihydroceramide desaturase by the sphingosine kinase inhibitors, SKi or ABC294640, induces growth arrest in androgen-independent LNCaP-AI prostate cancer cells. Oncotarget 7: 16663-16675, 2016.

83. Li PH, Wu JX, Zheng JN and Pei DS: A sphingosine kinase-1 inhibitor, SKI-II, induces growth inhibition and apoptosis in human gastric cancer cells. Asian Pac J Cancer Prev 15: 10381-10385, 2014

84. Liu Y, Zhu Z, Cai H, Liu Q, Zhou H and Zhu Z: SKI-II reverses the chemoresistance of SGC7901/DDP gastric cancer cells. Oncol Lett 8: 367-373, 2014.

85. Roviezzo F, Sorrentino R, Bertolino A, De Gruttola L, Terlizzi M, Pinto A, Napolitano M, Castello G, D'Agostino B, Ianaro A, et al: S1P-induced airway smooth muscle hyperresponsiveness and lung inflammation in vivo: Molecular and cellular mechanisms. Br J Pharmacol 172: 1882-1893, 2015.

86. Lin CC, Lee IT, Hsu CH, Hsu CK, Chi PL, Hsiao LD and Yang CM: Sphingosine-1-phosphate mediates ICAM-1dependent monocyte adhesion through p38 MAPK and p42/p44 MAPK-dependent Akt activation. PLoS One 10: e0118473, 2015

87. Völzke A, Koch A, Meyer Zu Heringdorf D, Huwiler A and Pfeilschifter J: Sphingosine 1-phosphate (S1P) induces COX-2 expression and $\mathrm{PGE}_{2}$ formation via $\mathrm{S} 1 \mathrm{P}$ receptor 2 in renal mesangial cells. Biochim Biophys Acta 1841: 11-21, 2014.

88. Selb R, Eckl-Dorna J, Twaroch TE, Lupinek C, Teufelberger A, Hofer G, Focke-Tejkl M, Gepp B, Linhart B, Breiteneder H, et al: Critical and direct involvement of the CD23 stalk region in IgE binding. J Allergy Clin Immunol 139: 281-289.e5, 2017.

89. Galli SJ and Tsai M: IgE and mast cells in allergic disease. Nat Med 18: 693-704, 2012

90. Melendez AJ: Allergy therapy: The therapeutic potential of targeting sphingosine kinase signalling in mast cells. Eur J Immunol 38: 2969-2974, 2008. 
91. Kunisawa J, Kurashima Y, Gohda M, Higuchi M, Ishikawa I, Miura F, Ogahara I and Kiyono H: Sphingosine 1-phosphate regulates peritoneal B-cell trafficking for subsequent intestinal IgA production. Blood 109: 3749-3756, 2007.

92. Garris CS, Blaho VA, Hla T and Han MH: Sphingosine-1phosphate receptor 1 signalling in T cells: Trafficking and beyond. Immunology 142: 347-353, 2014.

93. Matloubian M, Lo CG, Cinamon G, Lesneski MJ, Xu Y, Brinkmann V, Allende ML, Proia RL and Cyster JG: Lymphocyte egress from thymus and peripheral lymphoid organs is dependent on S1P receptor 1. Nature 427: 355-360, 2004

94. Rivera J, Proia RL and Olivera A: The alliance of sphingosine1-phosphate and its receptors in immunity. Nat Rev Immunol 8 : 753-763, 2008.

95.Lai WQ, Goh HH, Bao Z, Wong WS, Melendez AJ and Leung BP: The role of sphingosine kinase in a murine model of allergic asthma. J Immunol 180: 4323-4329, 2008.

96. Price MM, Oskeritzian CA, Falanga YT, Harikumar KB, Allegood JC, Alvarez SE, Conrad D, Ryan JJ, Milstien S and Spiegel S: A specific sphingosine kinase 1 inhibitor attenuates airway hyperresponsiveness and inflammation in a mast celldependent murine model of allergic asthma. J Allergy Clin Immunol 131: 501-11.e1, 2013.

97.Levkau B: Cardiovascular effects of sphingosine-1-phosphate (S1P). Handb Exp Pharmacol 216: 147-170, 2013.

98. Argraves KM and Argraves WS: HDL serves as a S1P signaling platform mediating a multitude of cardiovascular effects. J Lipid Res 48: 2325-2333, 2007.

99.Levkau B: HDL-S1P: Cardiovascular functions, diseaseassociated alterations, and therapeutic applications. Front Pharmacol 6: 243, 2015.

100. Jing XD, Wei XM, Deng SB, Du JL, Liu YJ and She Q: The relationship between the high-density lipoprotein (HDL)-associated sphingosine-1-phosphate (S1P) and coronary in-stent restenosis. Clin Chim Acta 446: 248-252, 2015.

101.Pchejetski D, Foussal C, Alfarano C, Lairez O, Calise D, Guilbeau-Frugier C, Schaak S, Seguelas MH, Wanecq E, Valet $\mathrm{P}$, et al: Apelin prevents cardiac fibroblast activation and collagen production through inhibition of sphingosine kinase 1. Eur Heart J 33: 2360-2369, 2012

102.Frias MA, James RW, Gerber-Wicht C and Lang U: Native and reconstituted HDL activate Stat 3 in ventricular cardiomyocytes via ERK1/2: Role of sphingosine-1-phosphate. Cardiovasc Res 82: 313-323, 2009

103. Whetzel AM, Bolick DT, Srinivasan S, Macdonald TL, Morris MA, Ley K and Hedrick CC: Sphingosine-1 phosphate prevents monocyte/endothelial interactions in type 1 diabetic NOD mice through activation of the S1P1 receptor. Circ Res 99: 731-739, 2006

104.Zhang F, Xia Y, Yan W, Zhang H, Zhou F, Zhao S, Wang W, Zhu D, Xin C, Lee Y, et al: Sphingosine 1-phosphate signaling contributes to cardiac inflammation, dysfunction, and remodeling following myocardial infarction. Am J Physiol Heart Circ Physiol 310: H250-H261, 2016.

105. Li N and Zhang F: Implication of sphingosin-1-phosphate in cardiovascular regulation. Front Biosci (Landmark Ed) 21: 1296-1313, 2016.

106. Keul P, van Borren MM, Ghanem A, Müller FU, Baartscheer A, Verkerk AO, Stümpel F, Schulte JS, Hamdani N, Linke WA, et al: Sphingosine-1-phosphate receptor 1 regulates cardiac function by modulating $\mathrm{Ca}^{2+}$ sensitivity and $\mathrm{Na}^{+} / \mathrm{H}^{+}$exchange and mediates protection by ischemic preconditioning. J Am Heart Assoc 5: 5, 2016

107. Song J, Hagiya H, Kurata H, Mizuno H and Ito T: Prevention of GVHD and graft rejection by a new S1P receptor agonist, $\mathrm{W}-061$, in rat small bowel transplantation. Transpl Immunol 26: $163-170,2012$

108. Trayssac M, Galvani S, Augé N, Sabbadini R, Calise D, Mucher E, Sallusto F, Thomsen M, Salvayre R and Nègre-Salvayre A: Role of sphingosine-1-phosphate in transplant vasculopathy evoked by anti-HLA antibody. Am J Transplant 15: 2050-2061, 2015.

109. Sanna MG,Liao J,JoE, Alfonso C, Ahn MY,Peterson MS, Webb B, Lefebvre S, Chun J, Gray N, et al: Sphingosine 1-phosphate (S1P) receptor subtypes S1P1 and S1P3, respectively, regulate lymphocyte recirculation and heart rate. J Biol Chem 279 $13839-13848,2004$.
110. Brinkmann V, Cyster JG and Hla T: FTY720: Sphingosine 1-phosphate receptor-1 in the control of lymphocyte egress and endothelial barrier function. Am J Transplant 4: 1019-1025, 2004

111. Li Q, Wang C, Zhang Q, Tang C, Li N and Li J: The reduction of allograft arteriosclerosis in intestinal transplant is associated with sphingosine kinase 1/sphingosine-1-phosphate signaling after fish oil treatment. Transplantation 93: 989-996, 2012.

112. Chiba K1, Yanagawa Y, Masubuchi Y, Kataoka H, Kawaguchi T, Ohtsuki M and Hoshino Y: FTY720, a novel immunosuppressant, induces sequestration of circulating mature lymphocytes by acceleration of lymphocyte homing in rats. I. FTY720 selectively decreases the number of circulating mature lymphocytes by acceleration of lymphocyte homing. J Immunol 160: 5037-5044, 1998.

113. Zhang J, Zhang A, Sun Y, Cao X and Zhang N: Treatment with immunosuppressants FTY720 and tacrolimus promotes functional recovery after spinal cord injury in rats. Tohoku J Exp Med 219: 295-302, 2009

114. Yuzawa K, Fukunaga K and Ohkohchi N: Back transplantation for survival of the graft. Transplant Proc 37: 192-193, 2005.

115. Sugito K, Uekusa S, Kawashima H, Masuko T, Furuya T, Konuma N, Ohashi K, Inoue M, Ikeda T and Koshinaga T: Effect of combined treatment with FK506, FTY720, and ex vivo graft irradiation in rat small bowel transplantation: Expression of mucosal addressin cell adhesion molecule-1. Pediatr Transplant 14: 614-617, 2010

116. Lopes CT, Gallo AP, Palma PV, Cury PM and Bueno V: Skin allograft survival and analysis of renal parameters after FTY720 + tacrolimus treatment in mice. Transplant Proc 40: 856-860, 2008.

117. Pyne S, Adams DR and Pyne NJ: Sphingosine 1-phosphate and sphingosine kinases in health and disease: Recent advances. Prog Lipid Res 62: 93-106, 2016.

118. Sivasubramanian M, Kanagaraj N, Dheen ST and Tay SS: Sphingosine kinase 2 and sphingosine-1-phosphate promotes mitochondrial function in dopaminergic neurons of mouse model of Parkinson's disease and in $\mathrm{MPP}^{+}$-treated MN9D cells in vitro. Neuroscience 290: 636-648, 2015

119. Pyszko J and Strosznajder JB: Sphingosine kinase 1 and sphingosine-1-phosphate in oxidative stress evoked by 1-methyl4-phenylpyridinium $\left(\mathrm{MPP}^{+}\right)$in human dopaminergic neuronal cells. Mol Neurobiol 50: 38-48, 2014

120.Zhang Y, Yu Q, Lai TB, Yang Y, Li G and Sun SG: Effects of small interfering RNA targeting sphingosine kinase-1 gene on the animal model of Alzheimer's disease. J Huazhong Univ Sci Technolog Med Sci 33: 427-432, 2013.

121. Yang Y, Wang M, Lv B, Ma R, Hu J, Dun Y, Sun S and Li G: Sphingosine kinase-1 protects differentiated N2a cells against beta-amyloid25-35-induced neurotoxicity via the mitochondrial pathway. Neurochem Res 39: 932-940, 2014.

122. Yi H, Lee SJ, Lee J, Myung CS, Park WK, Lim HJ, Lee GH, Kong JY and Cho H: Sphingosylphosphorylcholine attenuated $\beta$-amyloid production by reducing BACE1 expression and catalysis in PC12 cells. Neurochem Res 36: 2083-2090, 2011.

123. Takasugi N, Sasaki T, Suzuki K, Osawa S, Isshiki H, Hori Y, Shimada N, Higo T, Yokoshima S, Fukuyama T, et al: BACE1 activity is modulated by cell-associated sphingosine1-phosphate. J Neurosci 31: 6850-6857, 2011.

124. Canlas J, Holt P, Carroll A, Rix S, Ryan P, Davies L, Matusica D, Pitson SM, Jessup CF, Gibbins IL, et al: Sphingosine kinase 2 -deficiency mediated changes in spinal pain processing. Front Mol Neurosci 8: 29, 2015.

125. Hunter SF, Bowen JD and Reder AT: The direct effects of fingolimod in the central nervous system: Implications for relapsing multiple sclerosis. CNS Drugs 30: 135-147, 2016.

126. Aurelio L, Scullino CV, Pitman MR, Sexton A, Oliver V, Davies L, Rebello RJ, Furic L, Creek DJ, Pitson SM, et al: From sphingosine kinase to dihydroceramide desaturase: A structureactivity relationship (SAR) study of the enzyme inhibitory and anticancer activity of 4-((4-(4-chlorophenyl)thiazol-2-yl)amino) phenol (SKI-II). J Med Chem 59: 965-984, 2016. 